\title{
INVENTÁŘ TENDENCE K VINĚ A HANBĚ (ITVAH): PILOTNÍ STUDIE
}

\author{
Patrik Rudolf, Petra Hubatková, David Kremenik, Vit Kratochvíl, Adam Ť́ápal, Hynek Cígler
}

\begin{abstract}
Abstrakt
Tato studie je pilotáží nové metody pro měření náchylnosti k proživání viny a hanby, Inventáře tendence $k$ vině a hanbě (ITVAH). ITVAH je metoda založená na použití scénářů, která rozlišuje afektivní a behaviorální složky těchto dispozic a zároveň zohledňuje soukromé, resp. veřejné prožívání viny a hanby. Pro každý z 16 scénářủ byly vytvořeny dvě položky - afektivní a behaviorální reakce, čímž vzniklo celkem 32 položek. Byl předpokládán čtyřfaktorový model měření - Negativni hodnocení chování (NHCh), Náprava, Negativni hodnocení self $(N H S)$ a Únik. Dále byla předpokládána negativní souvislost NHS a Úniku se sebehodnocením a tendencí k sebeodpuštění a pozitivní souvislost $N H C h$ a Nápravy s tendencí k sebeodpuštění. Pilotní studie proběhla na vzorku 249 česky mluvících dospělých (67 \% žen, věk 18-75, Md =22). Na základě ordinální konfirmační faktorové analýzy se zohledněním reziduálních kovariancí mezi položkami vztahujících se ke stejnému scénáři jsme zjistili akceptovatelnou shodu předpokládaného modelu $\mathrm{s}$ daty. Pro předpokládané souvislosti se sebehodnocením a tendencí $\mathrm{k}$ sebeodpuštění jsme však získali pouze částečnou oporu, $\mathrm{v}$ rozporu s teoretickým očekáváním jsme zjistili středně silný negativní vztah mezi tendencí k sebeodpuštění a afektivní složkou viny. Pro širší používání této metody v československém prostředí je důležité dále ověřit konstruktovou validitu metody společně s ověřením souběžné validity s The Test Of SelfConscious Affect-3 (TOSCA-3).
\end{abstract}

Klíčová slova: tendence $\mathrm{k}$ vině, tendence $\mathrm{k}$ hanbě, individuální rozdíly, psychometrika

\section{INVENTORY OF PRONENESS TO GUILT AND SHAME: A PILOT STUDY}

Abstract

This paper constitutes a pilot study of a novel measure for assessing proneness to guilt and proneness to shame, Inventár tendence $k$ vině a hanbě (ITVAH, Inventory of Proneness to Guilt and Shame). ITVAH is a scenario-based method distinguishing affective and behavioural components of guilt and shame and also considering the private or public experience of guilt and shame, respectively. Two items (affective and behavioural reaction) were created for each of the 16 scenarios, resulting in total of 32 items. A four-factor measurement model was assumed - Negative behaviour evaluation (NBE), Reparation, Negative self-evaluation (NSE), Withdrawal. Next, we assumed negative correlations of NSE and Withdrawal with self-esteem and self-forgiveness and positive correlations of NBE and Reparation with self-forgiveness. The pilot study was carried out on 249 Czech-speaking adults (67\% women, aged $18-75, M d=22)$. An ordinal confirmatory factor analysis with residual covariances between items connected to the same scenarios was conducted. The hypothesized four-factor model was found acceptable. However, we found limited evidence for the hypothesized relationships with self-esteem and self-forgiveness - in contrast to theoretical expectations we found a medium-strong negative relationship between self-forgiveness and affective component of guilt. For further use of the measure in the Czech and Slovak environment it is necessary to assess additional evidence of construct validity and concurrent validity with The Test of Self-Conscious Affect-3 (TOSCA-3).

Key words: guilt-proneness, shame-proneness, individual differences, psychometrics

Došlo: 6. 1.2020

Schváleno: 13. 10. 2020 


\section{Úvod}

Vinu a hanbu lze označit za tzv. morální (též sebevztažné) emoce vyvolávané v situacích selhání nebo překročení určitých norem a vedoucí k reflexi a regulaci sociálně nežádoucího chování (Tangney, Youman, \& Stuewig, 2009; Tracy \& Robins, 2004). Jak vina, tak hanba mohou vznikat v podobném typu situací. Způsob jejich prožívání se nicméně liší a nese s sebou odlišné projevy. Vina je obecně vnímána jako adaptivnější emoce, která vede ke konstruktivnějšímu jednání a není tolik ohrožující pro celkové hodnocení vlastního já, zatímco hanba je považována za spíše maladaptivní emoci s destruktivnějšími dopady jak na mezilidské vztahy, tak sebehodnocení (Tangney, 1995). Přestože většina lidí ve svém životě do jisté míry zakouší obě emoce, mohou mít jednotlivci v obecné rovině tendenci prožívat jednu a/nebo druhou emoci ve větší či menší míře. Tyto dvě tendence jsou označovány jako náchylnost ${ }^{1}$ $k$ proživání viny a náchylnost $k$ proživání hanby ${ }^{2}$ (např. Tangney et al., 2009). V českém prostředí momentálně není dostupná validizovaná metoda, která by byla schopna individuální rozdíly $\mathrm{v}$ obou uvedených konstruktech dostatečně dobře měřit. $\mathrm{V}$ předkládaném textu prezentujeme pilotní studii námi vytvořeného nového nástroje - Inventáře tendence $k$ vině $a$ hanbě (ITVAH).

\section{Teoretické zázemí}

Odlišit vinu a hanbu v běžném jazyce bývá relativně obtížné - lidé mají často sklon oba negativní pocity směšovat a souhrnně je označovat jako pocity viny (Tangney, 1995; Tangney et al., 2009). Jedno z široce akceptovaných rozlišení představila Lewisová (cit. dle Tangney et al., 2009), která vymezila vinu jako emoci, jejímž objektem negativní evaluace je chování a jeho důsledky, zatímco hanbu popsala jako emoci, při níž je negativně hodnoceno globální self. Hanba je proto spojena s pocity méněcennosti, neschopnosti nebo „malosti“. Toto vymezení je kompatibilní s obecnějším pojetím sebevztažných emocí Tracyové a Robinse (2004, 2006). Podle nich se hanba zaměřuje na globální, stabilní aspekty self (napřr. schopnosti), zatímco vina se zaměřuje na specifické, nestabilní prvky (např. nedostatek snahy v konkrétní situaci).

Vina a hanba tedy představují bolestivé a nepř́jemné prožitky, pocity hanby jsou nicméně v tomto ohledu chápány jako intenzivnější (Tangney, 1995; Tangney \& Dearing, 2002). Současně vede prožívání pocitů hanby k potřebě „úniku“ ze situace a stažení se do sebe (Tangney \& Dearing, 2002). Přestože vina představuje emoci působící taktéž bolest, její regulace probíhá jinými mechanismy. Pocity viny mohou totiž jedince motivovat k nápravnému jednání vedoucímu k odčinění dřivějšího špatného chování (Tangney \& Dearing, 2002).

Tyto tendence mohou souviset s tím, že je náchylnost k vině úzce spojena s empatí́, zatímco náchylnost k hanbě nemá s empatií žádný vztah (Leith \& Baumeister, 1998; Tangney, 1995). Rozdíly mezi náchylnostmi k prožívání viny a hanby lze pozorovat také $\mathrm{v}$ jejich psychologických korelátech. Vzhledem k tomu, že hanba, na rozdíl od viny, je úzce spjatá se znehodnoceným self, jedním z nejvýznamnějších korelátů náchylnosti k hanbě je právě nízké sebehodnocení (Porter et al., 2019) a také vysoká míra sebekritiky (Gilbert \& Irons, 2008). $\mathrm{S}$ vysokou mírou sebekritiky může souviset i záporný vztah náchylnosti k hanbě a tendence k sebeodpuštění, zatímco u náchylnosti k vině je tento vztah pozitivní (Carpenter et al., 2016).

\footnotetext{
${ }^{1} \mathrm{~V}$ souvislosti s oběma konstrukty užíváme termínů náchylnost a tendence synonymně.

${ }^{2} \mathrm{~V}$ textu používáme pro souhrnné označení těchto dispozic též zkrácenou variantu náchylnost $k$ vině a hanbě.
} 
Pocity hanby a viny lze podle některých autorů odlišit i na základě situací, které tyto pocity vyvolaly (Combs et al., 2010; Smith et al., 2002). Prožívání viny je podle nich spojeno se špatným skutkem, o kterém ostatní lidé nevědí. Prožívání je tedy „soukromé“. Naproti tomu pocity hanby jsou způsobovány spíše situacemi, ve kterých prohřešek vnímají i lidé kolem nás. Zde se jedná o „veřejné“ prožívání. Rozlišení viny a hanby skrze situace, které je způsobují, je ale některými autory odmítáno kvůli nedostatečnému empirickému podložení (Tangney, 1992; Tracy \& Robins, 2006).

\section{Měření náchylnosti k prožívání viny náchylnosti k prožívání hanby}

V současné době se pro měření náchylnosti k prožívání viny a náchylnosti k prožívání hanby nejvíce využívá třetí revize metody The Test of Self-Conscious Affect-3 (TOSCA-3; Tangney, Dearing, Wagner, \& Gramzow, 2000), která je založena na posuzování pravděpodobnosti reakcí uvedených u popsaných scénářů. Jednotlivé položky u každé situace měří náchylnost $\mathrm{k}$ hanbě, náchylnost $\mathrm{k}$ vině, externalizaci a nezájem. V českém a slovenském prostředí je $\mathrm{k}$ měření náchylnosti $\mathrm{k}$ vině a hanbě využíván test TOSCA-3 prakticky výhradně (např. Dvořáková, 2013; Kořínek et al., 2019; Látalová, 2017; Marcinechová \& Martinčeková, 2018; Škrdlík, 2019), přestože řada autorů tuto metodu kritizuje pro její konstruktovou podreprezentovanost a neschopnost dostatečně diferencovat mezi oběma konstrukty (Fontaine et al., 2001; Giner-Sorolla et al., 2011; Luyten et al., 2002). Cohenová, Wolf, Panter a Insko (2011) upozorňují na to, že se v TOSCA-3 prolínají emoční a behaviorální složky v položkách jednotlivých konstruktů. Tyto nedostatky se pokusili zohlednit v měřícím nástroji Guilt and Shame Proneness Scale (GASP, viz níže), z nějž do značné míry vychází také námi vytvářená metoda.

\section{Cíle studie}

Cílem této studie je vytvořit metodu, která kombinuje výhody a redukuje nedostatky obou zmíněných dotazníků, a následně provést pilotáž za účelem ověření její faktorové struktury a konstruktové validity. Výsledný nástroj $\mathrm{k}$ měření viny a hanby by měl mít čtyřfaktorovou strukturu a teoreticky očekávané vztahy s dalšími proměnnými. Na těchto předpokladech jsme formulovali následující hypotézy:

H1: Model měření ITVAH bude obsahovat následující faktory: Negativni hodnocení chování, Náprava, Negativní hodnocení self a Únik.

H2: Faktory Negativní hodnocení self a Únik negativně korelují se sebehodnocením.

H3: Mezi faktory viny (Negativní hodnocení chování a Náprava) a sebehodnocením není žádný vztah.

H4: Faktory Negativní hodnocení chování a Náprava pozitivně korelují s tendencí k sebeodpuštění.

H5: Faktory Negativní hodnocení self a Únik negativně korelují s tendencí k sebeodpuštění. 


\section{Metoda}

\section{Tvorba položek}

Inventár tendence $k$ vině a hanbě (ITVAH) navazuje na způsob měření náchylnosti k vině a hanbě pomocí scénářŭ, využívaný v TOSCA-3 (Tangney et al., 2000) i GASP (Cohen et al., 2011). Po vzoru novější metody GASP (Cohen et al., 2011) rozlišujeme u prožívání viny a hanby emocionální a behaviorální reakci. Tomu odpovídá předpokládaná čtyřfaktorová struktura, ITVAH - Negativní hodnocení chování (NHCh) a Náprava reprezentují afektivní, respektive behaviorální složku viny, Negativní hodnocení self(NHS) a Únik jsou analogickými dimenzemi u hanby. Na rozdíl od GASP, kde je na jeden scénář vždy navázána pouze jedna reakce, jsou v našem měřícím nástroji na jeden scénář navázány dvě položky odpovídající behaviorální a emocionální (resp. hodnotící) reakci. Na každý scénář viny je tak navázána jedna položka popisující NHCh (např̀. „Zpětně budete svého činu litovat“ po vyzrazení tajemství dobrého př́itele) a jedna položka popisující úmysl nebo vykonání nápravy situace (např. „Druhý den hodíte sousedovi do schránky peníze na opravu škody“ poté, co jste předchozího dne naboural(a) sousedovo auto). Na každý scénář hanby je navázána jedna položka popisující $N H S$ (napřr. „Budete se cítit jako špatný/á kamarád(ka) a nespolehlivý člověk" poté, co jste zapomněl(a) a nedorazil(a) na smluvenou schůzku s kamarádem) a jedna položka popisující únik ze situace (např. „Budete se šéfovi pár následujících dnů vyhýbat“ poté, co jste v práci něco rozbil(a) a šéf vás u toho přistihl). Respondenti na pětibodové Likertově škále značí výstižnost popsané reakce pro jejich osobu (nevystihuje - spišse nevystihuje - ani tak, ani tak - spiše vystihuje - vystihuje). Položky u jednoho scénáře jsou vždy seřazeny tak, že respondenti hodnotí nejdříve afektivní a následně behaviorální reakci. Předpokládáme, že rozlišení na afektivní a behaviorální složku viny a hanby u odpovědí na jednotlivé scénáře poskytne komplexnější náhled na prožívání viny a hanby. Současně tato struktura umožní sledovat vztah mezi emoční a behaviorální reakcí na stejný podnět.

ITVAH také zohledňuje vliv soukromého a veřejného prožívání pocitů viny a hanby (Combs et al., 2010; Smith et al., 2002). Osm scénářů obsahuje situace veřejného prožívání špatného skutku (hypoteticky vyvolávající pocity hanby), osm scénářu popisuje soukromé prožívání špatného skutku (hypoteticky vyvolávající pocity viny). ITVAH tak obsahuje celkem 16 scénářů s celkovým počtem 32 položek.

Při konstruování položek a scénár̆ů po obsahové stránce jsme vycházeli z teorie o projevech viny a hanby (viz Teoretické zázemi) a z nástroje GASP (Cohen et al., 2011). Na základě analýzy teorie a scénářù GASP jsme vyvodili fasety situací vyvolávající vinu a hanbu. Tyto fasety se staly podkladem nových scénářu a položek relevantních pro české kulturní prostředí (pro plné znění položek ITVAH viz Přílohu 1).

\section{Vzorek}

ITVAH je určen pro česky mluvící dospělé, stejná populace proto byla využita i pro pilotní ověření metody. Výzkumný soubor byl získán metodou př́ležitostného výběru. K oslovení účastníků jsme využili sdílení online dotazníku na sociální síti Facebook a jeho hromadné rozesílání prostřednictvím emailu. Celkově vyplnilo pilotážní dotazník 262 respondentů, z toho 13 respondentů neúplně. Do finálních analýz tak byly zahrnuty odpovědi 249 účastníků, z nichž 167 bylo žen, 59 mužů a 23 respondentů pohlaví neuvedlo. Věkové rozpětí účastníků bylo od 18 do 75 let $(M=26,4 ; S D=11,1 ; M d=22)$. Data byla sbírána pomocí platformy Qualtrics. 


\section{Způsoby analýzy a zpracování dat}

Faktorovou strukturu ITVAH jsme ověřili prostřednictvím ordinální konfirmační faktorové analýzy. Primárně jsme testovali čtyřfaktorový model s reziduálními kovariancemi mezi položkami vztahujícími se ke stejným scénár̆ům (Model 1, viz obrázek 1 v sekci Výsledky). U takových položek předpokládáme - jak u viny, tak hanby - sdílený specifický rozptyl daný obsahem situace. Je nezbytné zohlednit, že behaviorální reakci u př́slušného scénáře hodnotí respondenti vždy až po hodnocení reakce afektivní, což může hodnocení behaviorální reakce ovlivnit, a zvětšit tak sdílený specifický rozptyl obou položek.

Testovali jsme také alternativní model, který slučuje položky sytící NHCh a NHS do jednoho faktoru (Model 2). Tento model jsme se rozhodli zahrnout především pro kontrolu toho, jestli respondenti rozlišují mezi negativním hodnocením chování a self, pokud tyto dvě formy reakce nemají možnost bezprostředně u jednoho scénáře porovnat. Tangneyová (1995) totiž upozorňuje, že lidé sami mezi vinou a hanbou dost dobře rozlišovat neumí. Vzhledem ke struktuře ITVAH, kdy jeden scénáŕ je určen bud' pouze pro vinu, nebo pouze pro hanbu, se proto domníváme, že je vhodné kontrolovat, zda respondenti mezi hodnocením chování/self rozlišovali a zdali model slučující tyto dimenze nevysvětluje naše data lépe.

Reliabilitu jsme odhadovali pomocí hierarchické McDonaldovy omegy s korekcí dle Greena a Yangové (2009) využívané při ordinální CFA. Konstruktovou validitu jsme ověřovali na základě poznatků o souvislosti náchylnosti k vině a hanbě s tendencí k sebeodpuštění a sebehodnocením. Ve studii Carpentera a kol. (2016) byla korelace tendence k sebeodpuštění $\mathrm{s}$ náchylností $\mathrm{k}$ vině slabá a pozitivní, $r=0,23$, a s náchylností $\mathrm{k}$ hanbě střední a negativní, $r=-0,42$. Pro měření tendence k sebeodpuštění jsme použili The Heartland Forgiveness Scale (HFS; Thompson et al., 2005), přesněji její zkrácenou a přeloženou verzi (Hašková, 2011). Ve studii Portera a kol. (2019) náchylnost k hanbě korelovala negativně se sebehodnocením $(r=-0,24$ a $-0,26$ pro Únik a NHS v GASP, $r=-0,51$ pro celkovou náchylnost $\mathrm{k}$ hanbě v TOSCA-3). Sebehodnocení jsme měřili prostřednictvím Rosenbergovy škály sebehodnoceni (SES; Blatný \& Osecká, 1994).

Deskriptivní statistiky byly spočítány v programu jamovi (The jamovi project, 2019), konfirmační faktorové analýzy a strukturní modely v prostředí $\mathrm{R}$ za použití balíčků lavaan (Rosseel, 2012) a semTools (Jorgensen, Pornprasertmanit, Schoemann, Rossel, 2018).

\section{Výsledky}

\section{Deskriptivní statistiky}

Deskriptivní statistiky jednotlivých položek ITVAH uvádíme v tabulce 1. Rozložení odpovědí položek měřících vinu je zpravidla zleva zešikmené. Účastníci většinou odpovídají, že je „spíše vystihuje“ či „vystihuje“ jak reakce $N H C h$, tak reakce Nápravy. Tomuto trendu neodpovídají jen položky 10 a 28, které jsou naopak zešikmené zprava. Př́ičinou této odlišnosti může být, že v nich uvedené reakce k nápravě chování jsou př́lišs „obtížné“. Naprŕíklad ITVAH_10 obsahuje reakci: „Přiznáte se a nabídnete se, že pokutu zaplatíte sám/sama.“ 
Tabulka 1

Deskriptivni statistiky jednotlivých položek ITVAH

\begin{tabular}{|c|c|c|c|c|c|c|c|c|c|}
\hline & $\bar{M}$ & $S D$ & Skew. & Kur. & & $\bar{M}$ & $S D$ & Skew. & Kur. \\
\hline ITVAH_1 & 3,63 & 1,27 & $-0,78$ & $-0,56$ & ITVAH_17 & 4,06 & 1,11 & $-1,30$ & 1,02 \\
\hline ITVAH_2 & 3,86 & 1,13 & $-1,27$ & 0,95 & ITVAH_18 & 3,95 & 1,30 & $-1,12$ & 0,01 \\
\hline ITVAH_3 & 4,22 & 1,17 & $-1,54$ & 1,36 & ITVAH_19 & 4,40 & 0,86 & $-1,76$ & 3,39 \\
\hline ITVAH_4 & 3,42 & 1,32 & $-0,51$ & $-0,96$ & ITVAH_20 & 4,75 & 0,61 & $-3,24$ & 12,33 \\
\hline ITVAH_5 & 4,17 & 1,00 & $-1,37$ & 1,58 & ITVAH_21 & 2,70 & 1,20 & 0,10 & $-1,19$ \\
\hline ITVAH_6 & 1,63 & 0,99 & 1,80 & 2,82 & ITVAH_22 & 1,35 & 0,69 & 2,30 & 5,85 \\
\hline ITVAH_7 & 3,63 & 1,23 & $-0,64$ & $-0,70$ & ITVAH_23 & 3,85 & 1,11 & $-0,97$ & 0,35 \\
\hline ITVAH_8 & 2,53 & 1,32 & 0,38 & $-1,15$ & ITVAH_24 & 1,54 & 0,79 & 1,42 & 1,40 \\
\hline ITVAH_9 & 3,79 & 1,34 & $-0,67$ & $-0,91$ & ITVAH_25 & 4,38 & 0,85 & $-1,85$ & 4,00 \\
\hline ITVAH_10 & 2,42 & 1,29 & 0,49 & $-0,85$ & ITVAH_26 & 3,99 & 1,09 & $-0,98$ & 0,24 \\
\hline ITVAH_11 & 3,99 & 1,24 & $-1,20$ & 0,38 & ITVAH_27 & 4,24 & 0,92 & $-1,46$ & 2,03 \\
\hline ITVAH_12 & 3,46 & 1,26 & $-0,50$ & $-0,79$ & ITVAH_28 & 2,69 & 1,29 & 0,34 & $-1,03$ \\
\hline ITVAH_13 & 4,02 & 1,25 & $-1,18$ & 0,30 & ITVAH_29 & 3,02 & 1,19 & $-0,21$ & $-1,04$ \\
\hline ITVAH_14 & 2,11 & 1,31 & 0,83 & $-0,64$ & ITVAH_30 & 1,17 & 0,48 & 3,26 & 11,95 \\
\hline ITVAH_15 & 4,34 & 1,06 & $-1,91$ & 3,16 & ITVAH_31 & 4,02 & 0,96 & $-1,09$ & 0,96 \\
\hline ITVAH_16 & 2,09 & 1,26 & 0,84 & $-0,43$ & ITVAH_32 & 1,32 & 0,75 & 2,86 & 8,73 \\
\hline
\end{tabular}

Pozn.: NHCh $(1,3,9,11,17,19,25,27)$; Náprava $(2,4,10,12,18,20,26,28) ; \operatorname{NHS}(5,7,13,15$, 21, 23, 29, 31); Únik $(6,8,14,16,22,24,30,32)$

Položky měřící NHS jsou také zleva zešikmené až na položky 21 a 29. Tyto položky na rozdíl od ostatních nepopisují pouze nespecifické přisouzení negativního adjektiva sobě samému (např.: „Budete si připadat sobecký/á.“), ale používají výrazná označení explicitně vztažená k vlastní osobě jako „hrozný necita“ a „zlý člověk“. Položky měřící Únik ze situace jsou všechny zešikmené zprava.

\section{Faktorová struktura ITVAH}

V Modelu 1 jsme specifikovali čtyři faktory (NHCh, Náprava, NHS a Únik) a modelovali reziduální korelace vždy mezi dvěma položkami vztahujícímu se ke stejnému scénáři. Dále jsme modelovali reziduální korelaci položek ITVAH_6 a ITVAH_32 faktoru Únik. Obě totiž popisovaly podobný typ únikového chování, tedy nechut' vzít telefon.

V Modelu 2 byly specifikovány tři faktory, kterými byly Obecné negativní hodnocení, Náprava a Únik. Faktor Obecného negativního hodnocení vznikl sloučením faktorů NHCh a NHS důvodem byla silná korelace těchto faktorů v modelu $1(r=0,906)$. Reziduální korelace v modelu 2 byly povoleny stejně jako v modelu 1. Faktorovou strukturu obou modelů jsme ověřili pomocí ordinální CFA (weighted least squares mean and variance estimation). Indexy shody obou modelů s daty jsou zobrazeny v tabulce 2 . 
Tabulka 2

Shoda jednotlivých modelůs daty

\begin{tabular}{cccccc}
\hline Model & $\chi^{2}(\mathrm{df})$ & CFI & TLI & SRMR & RMSEA (90\% CI) \\
\hline 1 & $586,8(441)^{* * *}$ & 0,908 & 0,897 & 0,086 & $0,037(0,028 ; 0,044)$ \\
2 & $590,5(442)^{* * *}$ & 0,907 & 0,895 & 0,086 & $0,037(0,029 ; 0,044)$ \\
\hline
\end{tabular}

Pozn.: $* * * p<0,001$

Výsledky v tabulce 2 ukazují relativně dobrou shodu s daty u obou modelů. Inkrementální indexy CFI a TLI sice nedosahují doporučených hodnot $\geq 0,95$ (Hu \& Bentler, 1999), to je ale do jisté míry způsobeno nízkým RMSEA základního modelu $\left(R M S E A_{\text {null }}=0,183\right)$. Druhým důvodem je zřejmě mnoho nadbytečných parametrů v podobě reziduálních korelací položek (některé jsou velmi slabé, viz Př́lohu 2). Naopak absolutní indexy SRMR a RMSEA značí dobrou shodu modelu s daty a jsou u obou modelů prakticky totožné. Jelikož jsou modely vnořené ve striktním významu (odhadovány jsou totožné parametry, oba modely se liší pouze v jednom stupni volnosti daném zafixováním korelace mezi faktory NHCh a NHS na 1), provedli jsme jejich srovnání prostřednictvím rozdílu chí-kvadrát statistiky za užití metody satorra. 2000 , která je k dispozici v balíčku lavaan (Rosseel, 2012). Model 1 sice popsal data nepatrně lépe $\Delta \chi^{2}(1)=5,39, p=0,020$, a hodnoty inkrementálních indexů se u něj zdají být také mírně lepší, rozdíly jsou ale zanedbatelné. Vzhledem k téměř totožné shodě obou modelů $\mathrm{s}$ daty je otázkou, zda by model 2 neměl být vzhledem ke své úspornosti preferovanější a zda faktory NHCh a NHS nevyjadřují ve své podstatě to stejné. K této problematice se blíže vyjadřujeme $\mathrm{v}$ diskuzi. Dále nicméně pracujeme pouze $\mathrm{s}$ modelem 1 , který má prozatím pevnější oporu v teorii. Strukturní diagram tohoto modelu znázorňuje Obrázek 1, tabulka s hodnotami reziduálních korelací se nachází v Přilloze 2. 


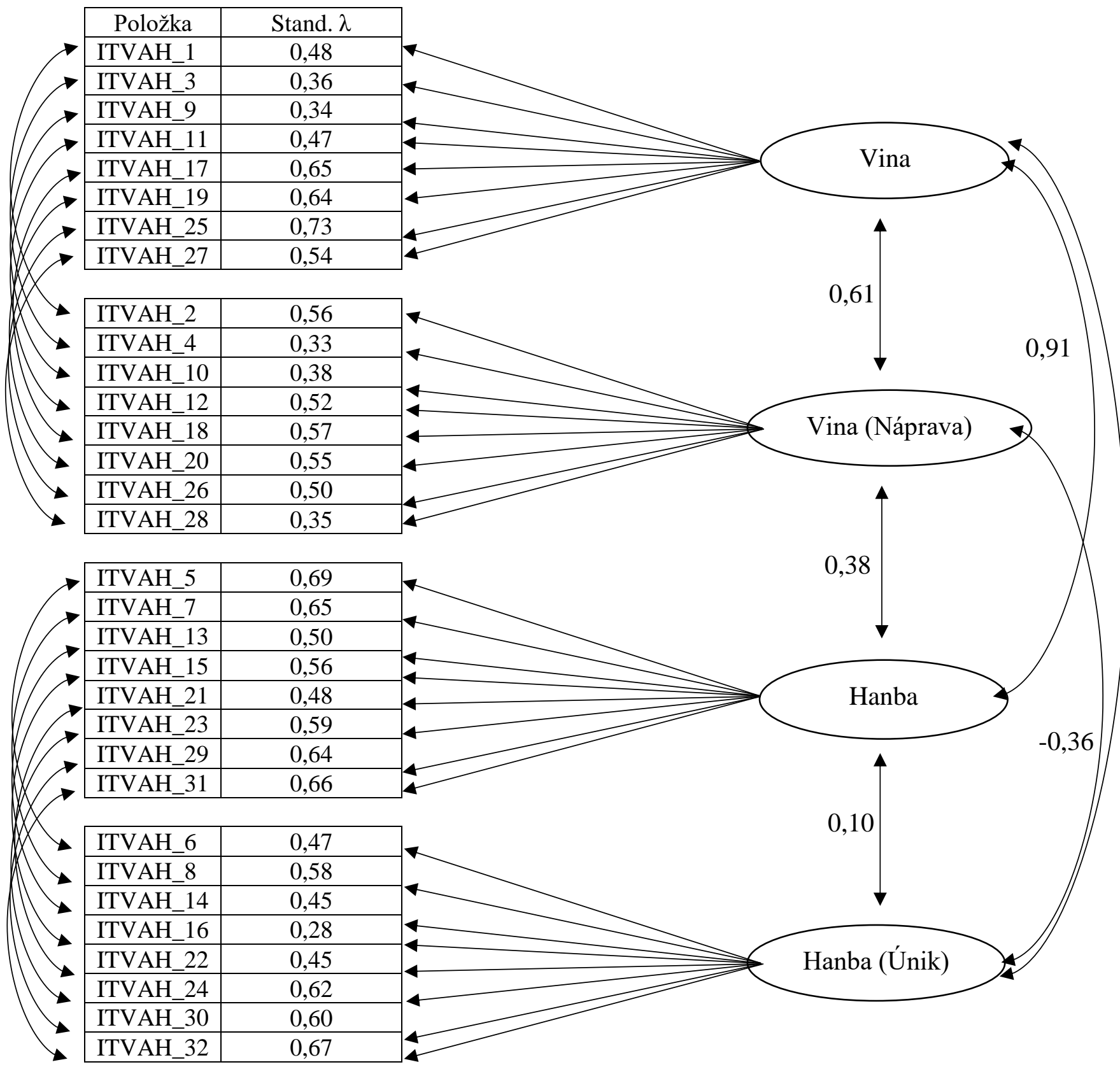

\section{Obrázek 1}

Strukturni diagram ordinálni CFA Modelu 1. Faktorové rozptyly byly fixovány na 1; prahy pro každou položku byly odhadnuty, ale nejsou zobrazeny.

\section{Souběžná a konstruktová validita ITVAH}

Hypotézy o konstruktové validitě předpokládají negativní vztah mezi dimenzemi ITVAH měřícími hanbu a sebehodnocením. V př́ípadě viny žádný vztah se sebehodnocením nepředpokládáme. Dále předpokládáme negativní vztah dimenzí hanby $\mathrm{s}$ tendencí $\mathrm{k}$ sebeodpuštění a pozitivní vztah dimenzí viny s tendencí k sebeodpuštění. Pro ověření těchto hypotéz jsme vytvořili strukturní model. Ten má relativně dobrou shodu modelu s daty, $\chi^{2}(1048)=1304$, $p<0,001, C F I=0,927, T L I=0,921, S R M R=0,084, R M S E A=0,031, C I_{90 \%}=[0,025 ; 0,037]$. 
V tabulce 3 uvádíme vzájemné korelace dimenzí ITVAH se sebehodnocením a tendencí k sebeodpuštění na latentní úrovni.

Tabulka 3

Matice latentnich korelaci dimenzi ITVAH, SES a HFS

1. ITVAH - Negativní hodnocen

\begin{tabular}{llllll}
1 & 2 & 3 & 4 & 5 & 6 \\
\hline- & & & & &
\end{tabular}

chování

2. ITVAH - Náprava

0,61

3. ITVAH - Negativní hodnocení

$0,90 \quad 0,37$
self

4. ITVAH - Únik

$-0,10 \quad-0,36 \quad 0,12$

5. Sebehodnocení (SES)

$\begin{array}{llll}-0,12 & 0,001 & -0,39 & -0,38\end{array}$

6. Tendence k sebeodpuštění (HFS)

$-0,37$

$-0,13$

$-0,5$

$-0,34 \quad 0,71$

Pozn.: $N=249$

Co se konstruktové validity týče, získali jsme podporu pouze pro část našich hypotéz. Sebehodnocení středně negativně koreluje s faktory NHS a Únik. Korelace sebehodnocení s dimenzemi viny jsou svou velikostí prakticky zanedbatelné. Dále byla nalezena silná negativní korelace tendence k sebeodpuštění s NHS a střední negativní korelace s Únikem. $\mathrm{V}$ rozporu $\mathrm{s}_{4}$ je ale střední negativní korelace tendence k sebeodpuštění s $N H C h$.

\section{Odhady reliability}

Reliabilitu jsme ověřovali pomocí McDonaldovy omegy s korekcí (Green \& Yang, 2009) pro každý ze čtyř faktorů zvlášt' (viz tabulku 4). Škály reprezentující emoční složky jednotlivých dispozic (NHCh a NHS) překračují akceptovatelnou hodnotu reliability 0,7 .

\begin{tabular}{lc} 
Tabulka 4 \\
McDonaldovy $\omega$ jednotlivých dimenzi ITVAH \\
\hline & McDonaldova $\mathbf{\omega}$ \\
\hline Vina (NHCh) & 0,730 \\
Vina (Náprava) & 0,599 \\
Hanba (NHS) & 0,781 \\
Hanba (Únik) & 0,624 \\
\hline
\end{tabular}

Behaviorální složky reakce se pohybují okolo hodnoty 0,6. Tyto hodnoty sice naznačují potenciálně velkou chybu měření, je ale potřeba zohlednit, že část specifického rozptylu jednotlivých položek je dána navázáním na konkrétní scénář, což mohlo přispět k nižším odhadům reliability. Uvedené hodnoty navíc přibližně korespondují s reliabilitami subškál jak v TOSCA-3 (Tangney \& Dearing, 2002), tak v GASP (Cohen et al., 2011). U obou uvedených dotazníků nicméně autoři odhadovali vnitřní konzistenci prostřednictvím Cronbachova alfa, jehož hodnota mohla být oproti skutečné hodnotě reliability podhodnocená. 


\section{Diskuze}

$\mathrm{V}$ této studii jsme prováděli pilotáž nové metody pro měření náchylnosti $\mathrm{k}$ vině a hanbě, Inventáre tendence $k$ vině a hanbě. V první části naší studie jsme testovali hypotézy o faktorové struktuře ITVAH. Ani jeden $\mathrm{z}$ testovaných modelů nedosáhl doporučovaných hodnot u inkrementálních indexů shody modelu s daty, ale oba dosáhly dobrých hodnot u absolutních indexů. Shoda modelu s daty čtyřfaktorového modelu je mírně lepší než u modelu tř́ffaktorového. Rozdíl mezi oběma modely je ale zanedbatelný. Mezi faktory NHCh a NHS byla navíc zjištěna velmi silná latentní korelace $r=0,91$. Její hodnota odpovídá vztahu mezi stejnými dimenzemi u metody GASP (Cohen et al., 2011; Studie 2), kde byla zjišš̌na vzájemná latentní korelace $r=0,84$.

Tato zjištění mohou na jedné straně vyvolávat pochybnosti o diferenciální validitě obou metod, na straně druhé mohou vést $\mathrm{k}$ úvaze, zda obě dimenze nevyjadřují ve své podstatě to stejné jakési obecné negativni hodnocení. Teorie nicméně naznačuje, že je potřeba mezi oběma dimenzemi rozlišovat (viz např. Tangney \& Dearing, 2002; Tracy \& Robins, 2004), což podporují jak naše zjištění, tak zjištění autorů GASP (Cohen et al., 2011). V případě konstruktové validity ITVAH totiž dimenze NHS středně silně negativně korelovala se sebehodnocením, zatímco vztah sebehodnocení s NHCh byl velmi slabý. Podobně Cohenová a kol. (2011) zjistili pozitivní vztah mezi NHS a ruminací (zatímco vztah NHCh a ruminace byl negativní) a nepřímý pozitivní vztah $N H S$ s depresivní symptomy mediovaný právě ruminací. Naopak vyšší míra NHCh souvisela s nižšśí mírou depresivity.

Na základě uvedeného usuzujeme, že by v rámci ITVAH nebylo přínosné slučování obou dimenzí do faktoru Obecného negativního hodnocení. Současně ale považujeme za vhodné zvážit, zda není pro respondenty problematické rozlišovat mezi negativním hodnocením chování a self. V ITVAH (podobně jako v GASP) totiž nikdy nejsou tyto dva typy reakce uvedeny u jednoho scénáře. Lidé tak mohou obě dimenze přes jejich obsahový rozdíl vnímat podobně. Jednou z variant možné modifikace ITVAH by proto mohlo být přiřazení všech čtyř forem reakcí k jednomu scénáři tak, aby byl více zřejmý jejich obsahový rozdíl. To s sebou ale nese dvě omezení - jednak se umocní vzájemná lokální závislost položek, jednak následně nemá smysl uvažovat o dimenzi soukromého/veřejného prožívání viny a hanby v rámci scénářů. Současně by ale takový krok umožnil jasněji detekovat, zda je prožívání obou emocí skutečně na tyto dimenze navázáno. V rámci budoucího ověrování validity ITVAH by proto mohlo být př́nosné porovnat mezi sebou různé formáty metody lišící se $\mathrm{v}$ počtu a typu položek navázaných na jeden scénár̆.

Zajímavým zjištěním je velmi nízká korelace mezi oběma dimenzemi hanby, která opět koresponduje se vztahy dimenzí v rámci GASP (Cohen et al., 2011). Lze se domnívat, že faktor Únik může být dimenzí schopnou rozlišovat jedince prožívající hanbu nepoměrně více než zbytek běžné populace. S ohledem na relativně vysokou korelaci faktoru NHS s NHCh a Nápravou, může být právě dimenze Únik tím, co přispívá k maladaptivnosti a destruktivnosti hanby. Cohenová a kol. (2011) dokonce uvažují nad tím, zda by Únik neměl být zbaven spojitosti s hanbou jakožto emocí a neměl by být spíše chápán jako tendence k určitému typu jednání. Nízká korelace mezi NHS a Únikem ale především poskytuje důležitý argument pro rozlišování behaviorální a emoční (hodnotící) složky při měření obou dispozic, což v případě TOSCA-3 (Tangney et al., 2000) chybí. 
Pro další práci s pilotovanou metodou je potřeba zvážit také pozměnění obsahu metody. Některé položky nejsou syceny př́slušnými faktory uspokojivě a bylo by vhodné jejich přeformulování. Dimenze viny nejhůře sytí položky 3, 9 (NHCh), 4 a 10 (Náprava) - u všech je standardizovaný náboj menší než 0,4 . Položky 3 a 4 jsou navázány na situaci, kdy v MHD jedete s jízdenkou jiného člověka, který následně dostane pokutu, položky 9 a 10 na situaci, kdy byl z opisování nařčen váš spolužák namísto vás. Položka 9 („Pomyslíte si, jak jste ušetřil(a)“") je jedinou reverzní položkou v ITVAH a lze pochybovat o tom, zda svým obsahem vyjadřuje opak NHCh. V prŕípadě položky 3 („Pomyslíte si, že jste neměl(a) opisovat") je otázkou, do jaké míry skutečně vyjadřuje emoční hodnotící reakci v porovnání s ostatními položkami NHCh. Položky 4 (,Vyučujícímu se přiznáte, že jste to byl(a) vy, kdo opisoval“) a 10 („Přiznáte se a nabídnete, že pokutu zaplatíte sám/sama“) jsou svou povahu relativně obtížné, a navíc v sobě zahrnují výrazné „,zveřejněni““ svého pochybení. Pokud při rozlišování mezi vinou a hanbou skutečně hraje roli dimenze soukromé-veřejné prožívání, je otázkou, zda tyto položky nepředstavují jakýsi hybrid mezi oběma emocemi a zda by se po uskutečnění uvedené reakce „nepřeklopil“ prožitek viny do prožitku hanby.

V př́padě faktoru NHS jsou náboje všech položek poměrně uspokojivé. Faktor Únik nejhůře sytí položku 16 („Na př́iští zastávce vystoupíte“ v situaci, kdy nepustíte sednout v MHD starší paní s berlemi), jejíž standardizovaný náboj je menší než 0,3 . Je možné, že v př́ípadě této položky měli respondenti problém se do situace vcítit. Pro starší respondenty se navíc uvedená situace nezdá být príliš relevantní.

Co se týče konstruktové validity, podrželi jsme pouze část hypotéz. Zjistili jsme středně silnou negativní souvislost dimenzí hanby se sebehodnocením. Dimenze viny se sebehodnocením nekorelují. $\mathrm{V}$ př́padě tendence $\mathrm{k}$ sebeodpuštění jsme získali podporu pro předpokládaný negativní vztah s dimenzemi hanby, současně jsme ale zjistili také slabou až střední negativní korelaci s dimenzí $N H C h$. To je v rozporu s naší hypotézou o pozitivním vztahu tendence $\mathrm{k}$ vině a sebeodpuštění. Zjištění Carpentera a kol. (2016) nicméně naznačují, že jednotlivé komponenty viny nemusí mít k sebeodpuštění stejný vztah. Pouhé negativní ohodnocení chování totiž ještě nutně nemusí vést k odpuštění sobě samému, ale vztah může být mediován dimenzí Nápravy.

Za hlavní limit studie považujeme metodu výběru vzorku. Respondenty jsme získali př́ležitostným výběrem v online prostředí. Od toho se může odvíjet relativní homogenita vzorku, v němž převažují spíše mladší respondenti, ačkoliv je ITVAH zamýšlen pro dospělou česko-slovenskou populaci. Zobecnění na cílovou populaci (např. na obyvatele České republiky) proto v současné chvíli není možné. Potenciální limit spatřujeme také ve velikosti vzorku. Vzhledem k množství odhadovaných parametrů v testovaných modelech, nemusel být počet odpovědí dostačující pro získání nezkreslených odhadů jednotlivých parametrů. $\mathrm{Z}$ uvedených důvodů je nutné ověřit model měření ITVAH i jeho konstruktovou validitu na vzorku výrazně větším, reflektujícím svými charakteristikami demografické složení české (a potažmo slovenské) populace. Výsledky této studie tak nabízejí pouze pilotní náhled na fungování ITVAH. Je proto nezbytné na ně nahlížet s vědomím uvedených limitů.

Pro širší využití metody ITVAH za účelem měření individuálních rozdílů v náchylnosti k prožívání viny a hanby je nezbytné dále ověřit její validitu, především její souvislost s dalšími psychologickými konstrukty. Důležitým cílem by také mělo být ověření souběžné validity ITVAH s TOSCA-3, která je v českém prostředí využívána $\mathrm{k}$ měření tendence $\mathrm{k}$ vině a hanbě 
prakticky výhradně. Další ověřování validity ITVAH by mělo být provedeno na několikanásobně větším vzorku reflektujícím svým složením demografické charakteristiky české (a potažmo slovenské) populace. V budoucím výzkumu by bylo také vhodné pozměnit některé položky se slabými faktorovými náboji. Zároveň by ITVAH mohl být upraven tak, že k jednomu scénáři budou přriřazeny všechny čtyři formy reakcí, aby se dalo lépe určit, nakolik a jakým způsobem jsou náchylnosti k vině a hanbě vzájemně propojeny.

\section{Literatura}

Blatný, M., \& Osecká, L. (1994). Rosenbergova škála sebehodnocení: Struktura globálního vztahu k sobě. Československá psychologie, 38(6), 481-488.

Carpenter, T. P., Tignor, S. M., Tsang, J.-A., \& Willett, A. (2016). Dispositional selfforgiveness, guilt- and shame-proneness, and the roles of motivational tendencies. Personality and Individual Differences, 98, 53-61. https://doi.org/10.1016/j.paid.2016.04.017

Cohen, T. R., Wolf, S. T., Panter, A. T., \& Insko, C. A. (2011). Introducing the GASP scale: A new measure of guilt and shame proneness. Journal of Personality and Social Psychology, 100(5), 947-966. https://doi.org/10.1037/a0022641

Combs, D. J. Y., Campbell, G., Jackson, M., \& Smith, R. H. (2010). Exploring the consequences of humiliating a moral transgressor. Basic and Applied Social Psychology, 32(2), 128-143. https://doi.org/10.1080/01973531003738379

Dvořáková, P. (2013). Tendence k proživání studu a tendence k proživání viny jako moderátory vztahu mezi interpersonální závislostí a vyhledáváním sociální opory. Diplomová práce. Brno: Masarykova univerzita, Fakulta sociálních studií. https://is.muni.cz/th/dlfsp/BP_Dvorakova.pdf

Fontaine, J. R., Luyten, P., De Boeck, P., \& Corveleyn, J. (2001). The Test of Self-Conscious Affect: Internal structure, differential scales and relationships with long-term affects. European Journal of Personality, 15(6), 449-463. https://doi.org/10-1002/per.428

Gilbert, P., \& Irons, C. (2008). Shame, self-criticism, and self-compassion in adolescence. In N. B. Allen \& L. B. Sheeber (Eds.), Adolescent emotional development and the emergence of depressive disorders (pp. 195-214). Cambridge: Cambridge University Press.

Giner-Sorolla, R., Piazza, J., \& Espinosa, P. (2011). What do the TOSCA guilt and shame scales really measure: Affect or action? Personality and Individual Differences, 51(4), 445-450. https://doi.org/10.1016/j.paid.2011.04.010

Green, S. B., \& Yang, Y. (2009). Reliability of summed item scores using structural equation modeling: An alternative to coefficient alpha. Psychometrika, 74(1), 155-167. https://doi.org/10.1007/s11336-008-9099-3

Hašková, J. (2011). Osobnostné súvislosti odpúštania sebe a iným. Diplomová práce. Brno: Masarykova univerzita, Fakulta sociálních studií. https://is.muni.cz/th/323495/fss_m/

Hu, L., \& Bentler, P. M. (1999). Cutoff criteria for fit indexes in covariance structure analysis: Conventional criteria versus new alternatives. Structural Equation Modeling: A Multidisciplinary Journal, 6(1), 1-55. https://doi.org/10.1080/10705519909540118

Jorgensen, T. D., Pornprasertmanit, S., Schoemann, A. M., \& Rossel, Y. (2018). semTools: Useful tools for structural equation modeling (Verze 0.5-1) [R package]. https://CRAN.R-project.org/package=semTools 
Kořínek, D., Benda, J., \& Žitník, J. (2019). Psychometrické charakteristiky krátké české verze dotazníku Pěti aspektů všímavosti (FFMQ-15-CZ). Československá psychologie, 63(1), $55-70$.

Látalová, A. (2017). Individuální rozdilly v citlivosti vůči odmítnutí: Souvislost s negativní afektivitou a tendenci k pocituim studu a viny. Diplomová práce. Brno: Masarykova univerzita, Fakulta sociálních studií. https://is.muni.cz/auth/th/va2qz/

Leith, K. P., \& Baumeister, R. F. (1998). Empathy, shame, guilt, and narratives of interpersonal conflicts: Guilt-prone people are better at perspective taking. Journal of Personality, 66(1), 1-37. https://doi.org/10.1111/1467-6494.00001

Luyten, P., Fontaine, J. R., \& Corveleyn, J. (2002). Does the Test of Self-Conscious Affect (TOSCA) measure maladaptive aspects of guilt and adaptive aspects of shame? An empirical investigation. Personality and Individual Differences, 33(8), 1373-1387. https://doi.org/10.1016/S0191-8869(02)00197-6

Marcinechová, D., \& Martinčeková, L. (2018). Odpustenie sebe a jeho súvislosti s tendenciou $\mathrm{k}$ vine, tendenciou $\mathrm{k}$ hanbe a empatiou u mladých dospelých. E-psychologie, 12(2), 115. https://doi.org/10.29364/epsy.316

Porter, A. C., Zelkowitz, R. L., Gist, D. C., \& Cole, D. A. (2019). Self-evaluation and depressive symptoms: A latent variable analysis of self-esteem, shame-proneness, and self-criticism. Journal of Psychopathology and Behavioral Assessment, 41, 257-270. https://doi.org/10.1007/s10862-019-09734-1

Rosseel, Y. (2012). lavaan: An R package for structural equation modeling. Journal of Statistiacl Software, 48(2). https://doi.org/10.18637/jss.v048.i02

Smith, R. H., Webster, J. M., Parrott, W. G., \& Eyre, H. L. (2002). The role of public exposure in moral and nonmoral shame and guilt. Journal of Personality and Social Psychology, 83(1), 138-159. https://doi.org/10.1037//0022-3514.83.1.138

Škrdlík, F. (2019). Neadekvátní pocity viny. Převod dotazníku IGQ-67 do češtiny. Diplomová práce. Brno: Masarykova univerzita, Fakulta sociálních studií. https://is.muni.cz/th/x660p/DP_FINAL_VERZE3.pdf

Tangney, J. P. (1992). Situational determinants of shame and guilt in young adulthood. Personality and Social Psychology Bulletin, 18(2), 199-206. https://doi.org/10.1177/0146167292182011

Tangney, J. P. (1995). Constructive and destructive aspects of shame and guilt. In A. C. Bohart \& D. J. Stipek (Eds.), Constructive \& destructive behavior: Implications for family, school, \& society (s. 127-145). Washington, DC: American Psychological Association.

Tangney, J. P., \& Dearing, R. L. (2002). Shame and guilt. The Guilford Press.

Tangney, J. P., Dearing, R. L., Wagner, P. E., \& Gramzow, R. (2000). The test of selfconscious affect-3 (TOSCA-3). George Manson University.

Tangney, J. P., Youman, K., \& Stuewig, J. (2009). Proneness to shame and proneness to guilt. In M. R. Leary \& R. H. Hoyle (Eds.), Handbook of individual differences in social behavior (pp. 192-209). New York: The Guilford Press.

The jamovi project. (2019). jamovi (Verze 0.9) [Počítačový software]. https://www.jamovi.org

Thompson, L. Y., Snyder, C. r., Hoffman, L., Michael, S. T., Rasmussen, H. N., Billings, L. S., Heinze, L., Neufeld, J. E., Shorey, H. S., Roberts, J. C., \& Roberts, D. E. (2005). Dispositional forgiveness of self, others, and situations. Journal of Personality, 73(2), 313-360. https://doi.org/10.1111/j.1467-6494.2005.00311.x 
Tracy, J. L., \& Robins, R. W. (2004). Putting the self into self-conscious emotions: A theoretical model. Psychological Inquiry, 15(2), 103-125. https://doi.org/10.1207/s15327965pli1502_01

Tracy, J. L., \& Robins, R. W. (2006). Appraisal antecedents of shame and guilt: Support for a theoretical model. Personality \& Social Psychology Bulletin, 32(10), 1339-1351. https://doi.org/10.1177/0146167206290212

Dostupnost výzkumných dat (odkazy na úložǐště): $\underline{\text { Dataset }} ; \underline{\mathrm{R} \text { skript }}$

Oba soubory lze otevř́t v programovacím jazyku R (respektive v kompatibilním softwaru RStudio).

\section{Př́lohy}

Příloha 1: Kompletní znění Inventáře tendence $k$ vině a hanbě

Před sebou máte nyní několik událostí, které se mohou běžnému člověku v průběhu života přihodit. U každé události jsou následně uvedeny dvě možné reakce na vzniklou situaci. Tyto reakce se nevylučují. Přečtěte si prosím vždy pozorně popis události a pokuste se do situace co nejvice vcítit. Následně zaznačte, jak moc vystihuje popis reakce na př́slušnou událost to, jak byste reagoval/a v reálném životě.

Slíbil(a) jste svému vedoucímu, že půjdete do práce i v sobotu dopoledne, abyste si dopracoval(a) chybějící hodiny. Bohužel ale $\mathbf{v}$ sobotu zaspíte a přijdete do práce až kolem jedenácté. $V$ sobotu na pracovišti ale nikdo není, takže o vašem pozdním př́íchodu nikdo neví.

(ITVAH_1) Budete si toto zaspání vyčítat.

(ITVAH_2) Zůstanete v práci i odpoledne.

Při zkoušce opíšete správné odpovědi od spolužáka. Zatímco vy získáte plný počet bodů, váš spolužák kvủli podežrení z opisování zkouškou neprojde.

(ITVAH_3) Pomyslíte si, že jste neměl(a) opisovat.

(ITVAH_4) Vyučujícímu se přiznáte, že jste to byl(a) vy, kdo opisoval.

Slíbíte kolegovi, že mu pomůžete vytvořit podklad k prezentaci jeho projektu před investory ve firmě. Na slib ale zapomenete a vzpomenete si na něj až večer před prezentací projektu, když vám kolega začne psát zprávy a bude se vám snažit dovolat.

(ITVAH_5) Budete si připadat neschopně a nezodpovědně.

(ITVAH_6) Nebudete mu brát telefony a odpovídat na zprávy.

$V$ práci jste něco rozbil(a) a šéf vás u toho přistihl.

(ITVAH_7) Budete se cítit jako nešikovný a neschopný člověk.

(ITVAH_8) Budete se šéfovi pár následujících dnů vyhýbat

Na zemi vedle automatu si všimnete ještě neprojeté jízdenky, vezmete si ji a nastoupíte do dopravního prostředku. Když přijde na kontrolu jízdenek, paní, co nastupovala na stejné zastávce jako vy, dostane pokutu, protože nemohla najít lístek, o kterém ale tvrdila, že si ho koupila a musel jí vypadnout.

(ITVAH_9) Pomyslíte si, jak jste ušetřil(a). 
(ITVAH_10) Přiznáte se a nabídnete se, že pokutu zaplatíte sám/sama.

Večer při parkování v místě, kde bydlíte, narazíte do sousedova auta tak, že mu promáčknete kapotu. Vaše auto vyvázne bez škrábnutí. Nikdo vás při nárazu neviděl, takže své auto přeparkujete tak, aby vás nikdo nemohl podezř́vat.

(ITVAH_11) Budete si vyčítat, že jste se sousedovi nepřiznal(a).

(ITVAH_12) Druhý den hodíte sousedovi do schránky peníze na opravu škody.

Jdete po ulici a na zemi uvidíte bezvládně ležícího člověka. Vy ale spěcháte na schůzku, a protože jsou kolem další lidé, tak mu nepomůžete a pokračujete dál.

(ITVAH_13) Budete si o sobě myslet, že jste špatný člověk.

(ITVAH_14) Ještě více přidáte do kroku.

V prostředku městské hromadné dopravy neuvolníte místo starší paní s berlemi.

(ITVAH_15) Budete si připadat sobecký/á.

(ITVAH_16) Na př́ští zastávce vystoupíte.

Jdete na návštěvu za svou babičkou do nemocnice a vaše matka vás požádá, abyste ji moc pozdravoval(a) a něco důležitého jí vyřídil(a). Při návštěvě na to ale zapomenete. Když už jste na cestě $z$ nemocnice, tak si na to vzpomenete.

(ITVAH_17) V duchu negativně ohodnotíte toto zapomenutí.

(ITVAH_18) Vrátíte se do nemocnice a babičce vše vyřídíte.

Na smluvenou schůzku dorazí váš partner/vaše partnerka s velkým zpožděním. Začnete mu/jí to vyčítat a pohádáte se. Doma ale při pohledu do diáře zjistíte, že jste to byl(a) vy, kdo dorazil na místo příliš brzy a váš partner přišel/vaše partnerka přišla včas.

(ITVAH_19) Kvůli vyvolání hádky se budete cítit hrozně.

(ITVAH_20) Partnerovi/partnerce řeknete pravdu a omluvíte se.

Kamarád vám vypráví historku, za kterou se prý velmi stydí. Vám ale jeho vyprávění připadá velmi vtipné, neudržíte se a začnete se smát.

(ITVAH_21) Napadne vás, že jste hrozný necita.

(ITVAH_22) Vymluvíte se, že spěcháte, a urychleně odejdete.

Při konverzaci s kamarádem záměrně řeknete lež, kterou on v průběhu konverzace s vámi odhalí.

(ITVAH_23) Budete se cítit jako prolhaný člověk.

(ITVAH_24) Přestanete se s ním vídat.

Vaši sousedi odjeli na dovolenou. Poprosili vás, abyste jim zalil(a) květiny, zatímco budou pryč. Bohužel jste na to ale zapomněl(a) a jedna drahá květina uvadla. Zítra se mají vaši sousedi vrátit.

(ITVAH_25) Budete naštvaní, že jste na to zapomněli.

(ITVAH_26) Koupíte sousedům tu stejnou kytku. 
Vyzradíte tajemství vašeho dobrého přítele. Ten se to nikdy nedozví.

(ITVAH_27) Zpětně budete svého činu litovat.

(ITVAH_28) Přiznáte se př́íteli k vyzrazení tajemství.

Váš kamarád se ve svém vztahu potýká $\mathrm{z}$ vašeho pohledu s triviálním problémem. Na vašem pravidelném setkání vás poprosí o radu. Vy jste ale po celém dni v práci unavení, a proto odpovíte trochu podrážděně.

(ITVAH_29) Budete si ř́íkat, že jste zlý člověk.

(ITVAH_30) Přestanete se s kamarádem stýkat.

S kamarádem jste si domluvil(a) schůzku, na kterou jste ale zapomněl(a) a nedorazil(a) na ni.

(ITVAH_31) Budete se cítit jako špatný/á kamarád(ka) a nespolehlivý člověk.

(ITVAH_32) Nebudete mu odepisovat na zprávy a nebudete mu zvedat telefon.

Pozn.: NHCh $(1,3,9,11,17,19,25,27)$; Náprava $(2,4,10,12,18,20,26,28)$; NHS $(5,7,13,15,21$, 23, 29, 31); Únik (6, 8, 14, 16, 22, 24, 30, 32)

Př́loha 2: Tabulka reziduálních korelací v modelu 1

\begin{tabular}{ccc}
\hline item1 & item2 & korelace \\
\hline ITVAH_1 & ITVAH_2 & 0,13 \\
ITVAH_3 & ITVAH_4 & 0,36 \\
ITVAH_9 & ITVAH_10 & 0,24 \\
ITVAH_11 & ITVAH_12 & 0,44 \\
ITVAH_17 & ITVAH_18 & 0,11 \\
ITVAH_19 & ITVAH_20 & 0,56 \\
ITVAH_25 & ITVAH_26 & 0,29 \\
ITVAH_27 & ITVAH_28 & 0,22 \\
ITVAH_5 & ITVAH_6 & 0,03 \\
ITVAH_7 & ITVAH_8 & 0,60 \\
ITVAH_13 & ITVAH_14 & $-0,16$ \\
ITVAH_15 & ITVAH_16 & 0,35 \\
ITVAH_21 & ITVAH_22 & 0,22 \\
ITVAH_23 & ITVAH_24 & 0,43 \\
ITVAH_29 & ITVAH_30 & 0,02 \\
ITVAH_31 & ITVAH_32 & $-0,11$ \\
ITVAH_6 & ITVAH_32 & 0,54 \\
\hline
\end{tabular}




\section{Údaje o autorech}

Patrik Rudolf je studentem navazujícího magisterského studia psychologie na Fakultě sociálních studií Masarykovy univerzity.

\section{Kontaktní údaje}

Adresa: Fakulta sociálních studií Masarykovy univerzity, Joštova 218/10, 60200 Brno

(shodná pro všechny autory)

E-mail: 471345@mail.muni.cz

Petra Hubatková je studentkou navazujícího magisterského studia psychologie na Fakultě sociálních studií Masarykovy univerzity.

E-mail: 469195@mail.muni.cz

David Kremeník je studentem navazujícího magisterského studia psychologie na Fakultě sociálních studií Masarykovy univerzity.

E-mail: 471324@mail.muni.cz

Vít Kratochvíl je studentem navazujícího magisterského studia na Fakultě sociálních studií Masarykovy univerzity.

E-mail:viita@mail.muni.cz

Mgr. Adam Ťápal, M.A. přednáší na katedře psychologie a je výzkumným pracovníkem v Institutu výzkumu dětí, mládeže a rodiny, Fakulta sociálních studií Masarykovy univerzity. E-mail: adam.tapal@mail.muni.cz

Mgr. Hynek Cígler, PhD. přednáší na katedře psychologie a je výzkumným pracovníkem v Institutu výzkumu dětí, mládeže a rodiny, Fakulta sociálních studií Masarykovy univerzity. E-mail: hynek.cigler@mail.muni.cz

Rudolf, P., Hubatková, P., Kremeník D., Kratochvíl, V., Ťápal, A., \& Cígler, H. (2020). Inventář tendence k vině a hanbě (ITVAH): pilotní studie. E-psychologie, 14(3), 49-65.

https://doi.org/10.29364/epsy.378 